\section{Briginal aldicles.}

\section{THE EXAMINATION OF THE FECES FOR THE STUDY OF THE FUNCTIONAL CONDITION OF THE ALIMENTARY TRACT IN CLINICAL WORK.}

An Experimental Study of the Schmidt and Strasburger Method OF Investigation OF the Condition of Function of the Alimentary Tract for the Digestion and Absorption of Food by Macroscopic and Microscopic Examination of THE FECES.

BY HENRY F. HEWES, M.D.,

Instructor in the Theory and Practice of Physic, Harvard Medical School; Physician to Out-Patients, Massachusetts General
Hospital, Boston.

(From the Laboratory of the Department of the Theory and Practice of Physic, Harvard Medical School.)

THE examination of the feces is to-day a recognized routine clinical method in the study of conditions of disease or disturbance of the alimentary tract, the stomach, intestines and large glands of the tract, the liver and pancreas. In this examination we may obtain evidences of the existence of definite diseased conditions of the tissues of the gut, as, for example, the presence of mucus or pus suggesting colitis or dysentery; the presence of blood from occult blecding suggesting ulcer or cancer of the gut; evidences of parasite infection of the gut in the presence of worms, worm eggs or segments, amcbæ coli, tubercle bacilli or other forms of specific bacteria; evidences of the existence of disturbance of the functional condition of the alimentary tract for digestion and absorption of the food as determined by the study of the food remains in the feces.

For the accomplishment of the first objects of research mentioned, the finding of definite pathological elements in the feces, a systematic study of any specimen of feces obtained by natural means will suffice. For the accomplishment of the second object of research, the study of the condition of the function of the tract, a specimen of feces obtained under the administration of a definite or test dict must be examined.

There are two general methods of examination of the special test diet feces for this purpose of determining the condition of the function of the body for the digestion and absorption of food products: (1) The chemical analysis for the determination of the content in various food products, proteid, carbohydrates, fat, neutral fat, soap, etc.; (2) the macroscopic and microscopic study of the feces for the observation of the visible food clements present, muscle fiber, starch, and fat in its various forms - neutral fat, soap, fatty acid.

Of these two methods, the first, the chemical analysis of the feces, is so difficult of accomplishment, its employment necessitating a great expenditure of labor and a considerable knowledge of chemical technic, that its general use in the routine practice of clinical medicine is impracticable.

We are, therefore, forced, in our investimation of this subject in connection with our cases in regular practice, to depend, as a rule, upon the second method of feces examination - the macroscopic and microscopic study of the visible and recognizable food elements. The principle of the method of the study of function by the macroscopic and microscopic examination of the feces consists in the comparison of the character of the food findings of our test case upon a definite diet with that of the feces of normal individuals upon a similar diet. If in our test case the character of any food finding, that, for example, of the meat remains, the starch or fat remains, differs from the normal, either qualitatively or quantitatively, we have evidence of some abnormality in the utilization of this food element. The existence of such an abnormality in the utilization of food substances indicates the presence of some disturbance of the functional activity of the alimentary tract, for clearly the presence of an extensive amount or abnormal character of the food remains of the feces indicates that the metamorphosis or disposal of food products is not going on in the normal manner.

The explanation of this failure of the alimentary tract to properly carry out its function for the utilization of food may lie in an inherent incapacity of one or several of the organs of digestion or absorption to function properly, due to disease or debility of the organ or disturbance of its innervation, or it may lie in the existence of an excessively active peristalsis of the intestines secondary to various causes, as inflammation or irritation of the tissues, a peristalsis which, by moving the food through the alimentary tract with abnormal rapidity, withholds from the organs the normal opportunity for digesting and absorbing the food, the capacity of the organs for these functions bcing itself unimpaired.

The object of our method of investigation is to discover conditions of the first class mentioned, conditions of primary disturbance of the functional capacity of the organs of digestion or absorption, to determine in any given case that these organs or the function of these organs are normal or abnormal as the case may be. The finding of a normal content of the test diet feces indicates a normal condition of these functions. The finding of an abnormal food content may or may not indicate a primary disturbance of these special functions of digestion or absorption, since, as we have stated, an abnormal finding may occur from a disturbance of peristaltic action of the intestines from any cause.

Such an abnormal finding is, however, our diagnostic sign of the existence of primary disturbance of the functions which we are investigating - digestion and absorption of food products. If this sign is lacking we can rule out such disturbance. If it is present, the existence of such disturbance is always suggested. Whether in any given case with this sign, the abnormal food finding, the disturbance of function is primary or secondary to peristalsis must 
If in such a case the feces are formed, excessive peristalsis may, of course, be ruled out, and the diagnosis of primary disturbance of the functions of digestion or absorption, according to the character of the food remains, may be made. If diarrhea is present, and one form of food substance, as, for example, fat, is much in excess of normal, the remaining forms, meat, remains and starch remains being normal or but slightly increased, we may still diagnosticate disturbance of digestion or absorption as a primary condition and assume this faulty utilization of a food product as a possible cause of our excessive peristalsis and diarrhea. For in diarrhea from excessive peristalsis alone, such as occurs with general inflammation of the intestinal mucosa or with irritation from poisonous food products, drugs, etc., all food elements are increased. If in diarrhea all foods are increased, or if signs of inflammation, colitis, enteritis, are present, we can draw no conclusion from our rescarch in regard to the primary condition of the organs of digestion and absorption for the performance of their functions.

In some cases of diarrhea positive conclusions cannot be made from one examination. For diagnosis we must await the advent of formed stools, or the results on the feces content obtained under treatment by variation in diet. Thus, in cases of faulty utilization of fat with diarrhea induced by the excessive intestinal content of fat, an excess of other food materials besides fat may occur as the result of the active peristalsis induced by the fat, without the existence of any inherent deficiency in the functions of digestion and absorption of these other food products. In such cases the great excess of fat present usually determines the diagnosis, but if it does not, the continued presence of the excess of fat with a return to normal in the amount of the other food products which occurs in formed fcces, when these are obtained in the case as a result of treatment, determines the point. As a rule, however, where a primary disturbance of function of digestion or absorption exists, the fact can be determined by the use of this method of study of a test diet feces by a single examination.

In the application of this method of study in clinical work we may use any form of test diet that suggests itself as useful for the particular case in hand. Thus we may feed the patient on a pure meat diet consisting of a definite quantity of meat in twenty-four hours, and thus by comparison of the finding with that of a normal individual on the same pure meat diet determine the capacity of the individual as to the digestion of meat. Or we may use a pure milk diet to determine by the fat finding the relative capacity for the utilization of milk fat present. All that is necessary is a set of standard norma records on our special diet for use in comparison with the finding of our special case.

As a routine practice, however, it is best in the employment of this method of research to use as a " test diet " not one single food substance, which enables us to determine the character of function in regard to one particular food only, but a diet made up of a mixture of various forms of foods, such as are ordinarily included in a normal diet list, - one, for example, containing definite amounts of the three principal food ele:nents, proteid, carbohydrates and fats.

With such a diet we can determine by a single experiment something of the functions of the individual for the utilization of all three of the above essential food elements under normal conditions of diet.

Schmidt and Strasburger, as the result of a long series of experiments, have developed a test diet of this kind, consisting of a mixture of various food clements, as meat, milk, potato, bread, which is admirably suited for this purpose of the study of function by the macroscopic and microscopic examination of the feces. ${ }^{1}$

The details of this method of examination of the feces, as outlined by Schmidt and Strasburger, are as follows: The patient is placed for a period of three to four days upon the following test diet régime:

Morning: 0.5 liter milk, $50 \mathrm{gm}$. zwieback.

Forenoon: 0.5 liter oatmeal gruel [made from $40 \mathrm{gm}$ oatmeal, $10 \mathrm{gm}$. butter, $200 \mathrm{gm}$. milk, $300 \mathrm{gm}$. water, 1 egg (strained)].

Noon: $125 \mathrm{gm}$. chopped beef (raw weight) broiled rare with $20 \mathrm{gm}$. butter, $250 \mathrm{gm}$. potato broth (made of $190 \mathrm{gm}$. mashed potatoes, $100 \mathrm{gm}$. milk, $10 \mathrm{gm}$. butter).

Afternoon: As morning.
Evening: As forenoon.

This diet consists of 1.5 liters milk, $100 \mathrm{gm}$. zwieback, 2 eggs, $50 \mathrm{gm}$. butter, $125 \mathrm{gm}$. beef, $190 \mathrm{gm}$. potatoes and $80 \mathrm{gm}$. oatmeal.

It contains about $102 \mathrm{gm}$. proteid, $111 \mathrm{gm}$. fat, $191 \mathrm{gm}$. carbohydrates.

The total calorie value (raw calories) is 2,234 .

This diet is given for a period of three to four days.

A stool which comes with certainty from this diet, the feces obtained on the third day of the régime, one evacuation having occurred on the second day, is collected and subjected to examination. The size of the stool, consistency and color are recorded. The feces is then mixed thoroughly with water and portions of the liquified mixture spread upon a plate and examined for macroscopic particles of food, notably remains of connective tissue and tendons, large masses of muscle tissue and potato granules. The nature of any such macroscopic particles suggesting food remains is confirmed by microscopic examination of the particles.

$A$ portion of the liquified feces is then ground with a pestle and a drop of the mixture placed on a slide under a cover slip and examined microscopically as to the presence of various food elements: viz., muscle fibers; starch granules free or in cellulose envelopes; fat remains in various forms, as neutral fat, fatty acid or various forms of soap. The recognition of starch can be aided by placing a drop of feces on a slide with some Lugol's iodine solution. Some idea 1 Schmidt und Strasburger: Die Faeces des Menschen. Berlin, 
of the quantity of fat elements present can be gained by heating a drop of feces on a slide with a drop of acetic acid and noting the resulting formation of fatty acid crystals which occurs as the specimen cools. The recognition of neutral fat drops can be facilitated by mixing a portion of the feces with an alcoholic solution of Soudan III and studying a drop of the mixture under the microscope. Neutral fat drops will stain a golden-red color.

The results of experience with the use of this method prove that the trained observer can, by its application, determine in a given case the following facts in regard to the utilization of food products in the alimentary tract: (1) Whether or not the digestion of meat muscle is normal or disturbed; (2) whether or not the digestion of starch is normal or disturbed; and, (3) something in regard to the normality or abnormality of both the digestion and absorption of fat.

The question of the condition of the function of the individual for the digestion of meat is determined by a study of the character of the meat remains present, the presence or absence of connective tissue, tendon tissue, the comparative quantity of muscle fiber present and the condition of digestion of this fiber.

According to Schmidt and Strasburger, in normal conditions no macroscopic masses of meat tissue should be found and the microscopic finding in this respect should show a limited number of isolated muscle fibers, of yellow color with rounded edges, with or without some indication of striation. The presence of macroscopic masses of meat tissue or of a greater number of muscle fibers in the microscopic finding than are present in the normal is indicative of a disturbance of the function of digestion of meat.

The question of the normality or abnormality of the digestion of starch is determined by the study of the potato and starch remains in the feces. In the normal, according to the authors, no macroscopic potato remains should be present and the microscopic findings show no free starch reacting to iodine, and only a few empty potato cells taking a very weak purple color with iodine. If macroscopic potato remains are present, or if the amount of starch seen microscopically in potato grains or free is excessive, the existence of a disturbance of the function of digestion of starch is indicated.

The question of the normality or abnormality of the utilization of fat is determined by the study of the visible fat remains in the feces. In normnl conditions of function the visible fat remains in the feces consist, according to Schmidt and Strasburger, of (1) salts of calcium soap appearing as small and large flakes of deep yellow color, (2) irregular masses of colorless soaps. ${ }^{2}$ The presence of a greater quantity of these fat elements in the forms mentioned than is found in

${ }^{2}$ According to the results of my investigation of the normal test diet feces the fat finding is more varied than that described by the authors of the method (see page 430). and the destructions between the normal and abnormal findings not as definite as described. the normal, or the presence of any amount of fat in a form not seen in normal test diet feces, as needles of soap or fatty acid, drops of neutral fat, indicates that the utilization of fat is less complete than is the rule in normal conditions. The common finding in cases of increased fat content in the feces is the presence of excessive numbers of splinter and needle forms of soap or fatty acid. This indicates a disturbance in the function of absorption of fats. The presence of any considerable amount of neutral fat drops suggests a disturbance of digestion of fat. Feces with an abnormal fat content give an excessive finding of fatty acid crystals in the specimen heated with acetic acid. ${ }^{2}$

A considerable experience with the use of this method of the macroscopic and microscopic examination of the test diet feces, as developed by Schmidt and Strasburger, has convinced me of the usefulness of the method in clinical work. The technic of the examination is very simple. The only training necessary for the observer is a facility in the recognition of the various food elements in the feces, muscle remains, starch remains and fat remains, and a familiarity with the characteristics of the normal test diet feces in respect to these food remains. To gain this training each student of the subject should make as a preliminary to the use of the method in general work a study of the feces of a considerable number of normal individuals. This will fix in his mind the normal picture with its variations in different individuals and give him a standard for comparison for use in his application of the method to the study of clinical cases. It is essential in my opinion that the knowledge of the observer in regard to this normal test diet feces should be based upon actual observation, covering a considerable number of cases, and not merely upon a reference to the descriptions of the normal findings as given by the authors of the method or other observers. It is true that these descriptions of Schmidt and Strasburger are very definite, but they are too definite. My own experience in the study of the normal test diet feces gained by the examination of a considerable number of normal individuals proved to me (1) that there is a considerable variation in the food finding of the feces in various normal individuals, and (2) that the finding may differ considerably from that described by Schmidt and Strasburger as the normal finding. This variation is particularly marked in regard to the fat findings. In my series of normal cases (see Table 1), the forms of recognizable fat substance present consisted of yellow masses of calcium soap, masses of colorless soap, splinters and needles of fat substance and rarely drops of neutral fat. In a majority of cases masses of calcium and of colorless soaps were the only forms present. In some cases splinters and needles of fat substance were also present in considerable numbers. Neutral fat was recognized in a few cases only, and in these cases the number of fat drops seen was very small, - five or six on a cover-slip preparation at most. The 
finding of fat in my cases differed from the descriptions of the normal test diet fat finding as given by Schmidt and Strasburger in the occasional presence of splinters and needles of fat substance and the rare presence of neutral fat drops. According to these authors, needles and neutral fat occur in test diet feces only in pathological conditions, the only forms of recognizable fat substance found in the normal being masses of calcium and colorless soaps. Those of my normal cases which showed the splinters and needles or the neutral fat drops were, it is true, all cases with a higher fat content than the average normal finding. They were, however, normal cases and prove that such findings may occur in normal conditions.

The total quantity of recognizable fat elements present showed much variation in my cases. In some cases where the only form present was that of soap masses, the quantity of these was slight; in others it was large. In some cases a few splinters were present in addition to the soap masses, and in some the splinters and needles of soap were fairly numerous. Neutral fat was, as stated, rarely present in recognizable forms, and then only in very small quantity. The findings of the other food elements, the meat remains and starch remains, showed some variation in different normal individuals, but, on the whole, tallied accurately with the descriptions of the authors of the method in regard to the normal feces.

A general use of the method will, however, convince the observer that in spite of the variation which may occur in the normal feces finding, particularly that present in regard to the fat content, the variation in the finding of many pathological cases beyond the limits of normal variation is so marked and so definite that it is a simple matter, in many cases, if not in all, to recognize definitely the presence of an abnormal food content of the feces in meat remains, starch remains or fat remains, as the case may be, where such a condition exists. That is, we can, as a result of the use of the method, say definitely, in a majority of cases, whether our food finding, as disclosed by the method of examination, is within the limits of the normal or whether it is abnormal as regards any or all of the food elements studied.

Whether or not the food findings as revealed by this method of macroscopic and microscopic examination of test diet feces are accurate indices of the condition of utilization of these special food substances studied, meat, starch and fat respectively, that is, whether a normal or abnormal microscopic finding of meat or starch or fat corresponds in all cases to a normal or abnormal fecal content respectively, in these substances, is, of course, another matter. A general consideration of the subject from this point of view, namely, a consideration of the question as to whether or not the microscopic food finding of the test diet feces is an accurate index of the character of the utilization of any particular food element present, tends to con- vince us as regards the first two food elements studied in the application of this method, the meat remains and the starch remains, that the microscopic finding must serve as a fairly accurate index of the utilization of these substances. That is, a finding of meat or starch remains, in excess of or differing from the normal finding, indicates conclusively that less meat or starch has been digested in the alimentary tract in the individual in question than in normal conditions, while the presence of a normal finding in this regard corresponds to a normal condition of utilization. This conclusion as regards the accuracy of the indications of the meat and starch findings would appear to need no experimental proof. For all the meat and starch appearing as such in the feces is in visible and recognizable form, and the more of these elements than normal on a given diet are present in the feces, a less quantity must by necessity have undergone utilization (digestion) in the alimentary tract. In the case of the third food element studied, the fat, the indications as regards the correspondence of the microscopic finding with. the actual quantity of fat content of the feces, that is, the evidences of the value of this microscopic finding as an index of the normality or abnormality of fat utilization in the alimentary tract, which can be obtained from general consideration, are, however, not equally clear or conclusive.

We are not in the case of fat, as in that of the muscle and starch remains, dealing with a substance of a definite morphological character which must necessarily, if it escapes utilization in the alimentary tract, appear in its original food form in the feces. The total fat content of the feces represents not simply the original food fat which escapes digestion, as in the case of the muscle and starch, but also whatever portion of the food fat after its digestion and metamorphosis in the intestine escapes absorption. The results of chemical analysis of the feces show that the fat content is made up of three general forms of fat - neutral fat, fatty acid and soap.

In an analysis of the test diet feces of 7 normal individuals, for example, the average finding of the fat content was as follows. (See Table, page 434.)

Total fat content of $1 \mathrm{gm}$. dried residue of feces: $225 \mathrm{mgm}$., or $22.5 \%$.

Total fatty acid: $86 \mathrm{mgm}$., or $37.9 \%$ of all fat present. Total soap: $74.7 \mathrm{mgm}$., or $33.4 \%$ of all fat present. Total neutral fat: 64.4 mgm., or $28.5 \%$ of all fat present.

A comparative study of the microscopic fat finding and the records of chemical analysis in these 7 cases shows, however, that while all contained, according to the analysis, considerable, often nearly equal, quantities of all these fat elements, in many of them the only form of fat morphologically recognizable by microscopic study was soap. Thus in Case I, for example, the only forms of fat recognized by microscopic examination were masses of calcium and colorless soaps, no neutral fat or fatty acids recognizable as such being recorded. Yet the feces contained, 
in addition to the soap, $73 \mathrm{mgm}$., or $28.8 \%$, of all fat in the form of neutral fat, and $97 \mathrm{mgm}$., or $38.1 \%$, of all fat in the form of fatty acid. It is clear, then, from expcrimental evidence, that considerable quantities of the fat of the test diet feces, particularly fat in the form of neutral fat and fatty acid, is present in a form unrecognizable by microscopic examination.

Such being the case, that is, it being an accepted proposition that considerable quantities of fat are present in the feces in a form unrecognizable by microscopic examination, the question at once arises as to whether the quantity of recognizable fat found by microscopic examination is necessarily an index of the actual fat content of the feces; that is, whether our method of study serves as a reliable means of judging of the normality or abnormality of the fat content of the feces at all. For if, as in many normal cases, all the neutral fat and fatty acid, amounting to 60 to $70 \%$ of all the fat of the feces, is present in an unrecognizable form, it would seem possible and even probable that a considerable increase of these fat substances, indicating a faulty utilization of fat, might occur without revealing itself in the microscopic finding. Also, much of the fat content of the feces having no definite morphological character, it would appear quite possible that the character of the fat remains, the amount and morphological character of the recognizable fat elements may be dependent upon certain characteristics of the fecal excretion entirely distinct from the quantity or quality of the fat content, as the reaction, the amount of calcium, the content in organic acids, and not necessarily bear any relation to the amount of fat content at all.

To settle this question as to the existence of any definite relationship between the microscopic finding of fat elements and the actual quantities or the character of the fat content present; whether, on the one hand, a condition of diminished utilization of fat as determined by the presence of an actual increase over normal of the total fat content of the feces is always accompanied by an abnormal microscopic fat finding, and, on the other hand, whether an abnormal microscopic finding of fat elements either in increased quantity of these elements or in qualitative variation from the normal in the character of the elements found, is always accompanied by an actual increase in the total fat or of some kind of fat present over the normal finding, I have made an experimental study consisting of an examination of the test diet feces in a series of 21 cases of normal and pathological conditions of function of utilization of fats, the examination in each case consisting of a record of the microscopic finding in recognizable fat elements, and a record of the actual fat content of the feces as determined by chemical analysis, both as to the total quantity of fat, and also the quantity of each of the three special forms of fat found in the feces, neutral fat, fatty acid and soap. A comparison of these two kinds of record, the physical (microscopic) and the chemical, in the scries of cases, gives us a definite evidence as to whether or not any correspondence or relationship between the character of the microscopic finding and the actual quantity or character of the fat content present exists as a general condition or rule, and, if so, what the extent of this relationship is and what practical application can be made of it for purposes of clinical work. ${ }^{3}$

The records of the experiment can be seen in the Table. ${ }^{4}$

The verdict of this experimental study upon the subject of the extent of the relationship between the finding of fat in the test diet feces as revealed by the microscopic examination and actual fat content of the feces, both the total quantity of fat and the proportionable quantity of the various forms of fat found in feces, ncutral fat, fatty acid and soaps, is as follows:

The character of the microscopic fat finding in the test diet feces as studied in normal and pathological conditions varies in the great majority of cases with the total quantity of fat present, the number of microscopically recognizable fat elements being proportionally greater as the total fat content increases. This variation in the microscopic finding may be both quantitative and qualitative. Thus there may be in a case with abnormal fat content an increase in all forms of recognizable fat elements, the masses of calcium or colorless soaps always present to some extent in normal feces, or the neutral fat drops rarely present in the normal; or the variation from the normal in the microscopic finding may consist entirely of an excessive finding of one special form of fat substance, morphologically considered, as, for example, the splinters and needles or the neutral fat drops.

A study of the records shows that in most, though not all, of the normal cases the only fat elements recognizable microscopically were masses of calcium or colorless soaps. (Cases I, II, VI, VII, VIII, X and XI.) As the quantities of fat, as determined by analysis, increase, splinters and needles of fat substance, and, in some cases, neutral fat drops, appear, with or without apparent increase in the soap masses. Thus the normal cases with high fat contents, as compared with the average normal finding, show more or less numerous splinters and some of them a rare drop of neutral fat in addition to the soap masses found equally in the cases with low fat content. (See Cases III, IV, V and IX.) In the pathological cases with abnormally high fat content, the splinters and needles or the neutral fat drops, one or both, are present in excessive numbers. In some of the cases studied the evidence of increased fat content in the microscopic finding consists principally of the excessive finding of splinters and needles with slight or no increase in the neutral fat drops 3 The method of analysis used is described in my article on the chemical analysis of the test diet feces of normal individuals. The Study of the Functions of the Alimentary Tract for the DigesAND SURG. Jour., vol. clviii, No. 19, p. 655 . AND SURG. JouR., vol. clviii, No. 19, p. 655. The material for this work was obtained principally from cases in the medical wards of the Massachusetts General
the use of which I am indebted to Dr. F. C. Shattuck. 
TABLE 1.

\begin{tabular}{|c|c|c|c|c|c|c|c|c|}
\hline \multirow{2}{*}{ Case. } & \multirow{2}{*}{$\begin{array}{c}\text { RACTER of Feces } \\
\text { AND Microscopic Finding } \\
\text { OF Fat Content. }\end{array}$} & \multirow{2}{*}{ 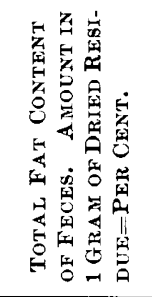 } & \multicolumn{2}{|c|}{ NeUtral Fat. } & \multicolumn{2}{|c|}{ FATty ACID. } & \multicolumn{2}{|c|}{ SoAP. } \\
\hline & & & $\begin{array}{l}\text { Amount } \\
\text { in } \\
1 \text { Gram. }\end{array}$ & $\begin{array}{l}\text { Propor- } \\
\text { tion of } \\
\text { All Fat. }\end{array}$ & $\begin{array}{l}\text { Amount } \\
\text { in } \\
1 \text { Gram. }\end{array}$ & $\begin{array}{l}\text { Propor- } \\
\text { tion of } \\
\text { All Fat. }\end{array}$ & $\begin{array}{l}\text { Amount } \\
\text { in } \\
1 \text { Gram. }\end{array}$ & $\begin{array}{l}\text { Propor- } \\
\text { tion of } \\
\text { All Fat. }\end{array}$ \\
\hline $\begin{array}{c}\text { I. } \\
\text { DAILYMIK. } \\
\text { Normal adult. }\end{array}$ & $\begin{array}{l}\text { One stool in } 24 \text { hours. Stool } \\
\text { well formed, normal size and } \\
\text { yellow color. } \\
\text { Fat content: Occasional } \\
\text { masses of calcium soap. Oc- } \\
\text { casional masses of colorless } \\
\text { soaps. No splinters or crys- } \\
\text { tals. No neutral fat. }\end{array}$ & $\begin{array}{c}255 \mathrm{mgm} . \\
25.5 \%\end{array}$ & $73 \mathrm{mgm}$. & $28.8 \%$ & $97 \mathrm{mgm}$. & $38.1 \%$ & $84 \mathrm{mgm}$. & $33.1 \%$ \\
\hline $\begin{array}{l}\text { II. } \\
\text { DEcost. } \\
\text { Normal } \\
\text { child of } 13 \text {. }\end{array}$ & $\begin{array}{l}\text { One stool in } 24 \text { hours. Well } \\
\text { formed. Color normal (yel- } \\
\text { low). } \\
\text { Fat: Some calcium and col- } \\
\text { orless soap masses. No splin- } \\
\text { ters or crystals. No neutral } \\
\text { fat. }\end{array}$ & $\begin{array}{c}202 \mathrm{mgm} . \\
20.2 \%\end{array}$ & $59 \mathrm{mgm}$. & $29.7 \%$ & $74 \mathrm{mgm}$. & $37.1 \%$ & $66 \mathrm{mgat}$ & $33.1 \%$ \\
\hline $\begin{array}{l}\text { III. } \\
\text { Bowles. } \\
\text { Normal child of } 13 .\end{array}$ & $\begin{array}{l}\text { One stool in } 24 \text { hours. Well } \\
\text { formed, yellow. } \\
\text { Fat: Many fat splinters and } \\
\text { crystals. Some calcium and } \\
\text { colorless soap masses. Rare } \\
\text { neutral fat drop. }\end{array}$ & $\begin{array}{c}330 \text { mgm. } \\
33 \%\end{array}$ & $106 \mathrm{mgm}$. & $32.2 \%$ & $117 \mathrm{mgm}$. & $35.7 \%$ & $105 \mathrm{mgm}$. & $32.1 \%$ \\
\hline $\begin{array}{l}\text { IV. } \\
\text { MurRay. } \\
\text { Adult. }\end{array}$ & $\begin{array}{l}\text { One stool in } 24 \text { hours. Well } \\
\text { formed, yellow. } \\
\text { Fat: Some splinters and } \\
\text { crystals. Some calcium and } \\
\text { colorless soap masses. Occa- } \\
\text { sional neutral fat drop. }\end{array}$ & $\begin{array}{c}310 \mathrm{mgm} . \\
31 \%\end{array}$ & $102 \mathrm{mgm}$. & $33.1 \%$ & $106 \mathrm{mgm}$. & $34.3 \%$ & $102 \mathrm{mgm}$. & $33.1 \%$ \\
\hline $\begin{array}{c}\text { V. } \\
\text { EGAN. } \\
\text { Child of 12. } \\
\text { Rheumatoid } \\
\text { arthritis. }\end{array}$ & $\begin{array}{l}\text { One stool in } 24 \text { hours. } \\
\text { Fat: Excessive quantity of } \\
\text { calcium soap masses. Rare } \\
\text { splinter or needle. No neu- } \\
\text { tral fat drops. }\end{array}$ & $\begin{array}{c}350 \mathrm{mgm} . \\
35 \%\end{array}$ & $102 \mathrm{mgm}$. & $33.1 \%$ & 106 mgm. & $34.3 \%$ & $102 \mathrm{mgm}$. & $33.1 \%$ \\
\hline $\begin{array}{l}\text { VI. } \\
\text { BAILEY. } \\
\text { Chronic ulcer of } \\
\text { stomach; opera- } \\
\text { tion. }\end{array}$ & $\begin{array}{l}\text { One stool in } 24 \text { hours. } \\
\text { Fat: Some masses of cal- } \\
\text { cium and colorless soaps. No } \\
\text { splinters. No neutral fat. }\end{array}$ & $\begin{array}{c}228 \text { mgm. } \\
22.8 \%\end{array}$ & $69 \mathrm{mgm}$. & $30.5 \%$ & $93 \mathrm{mgm}$. & $40 \%$ & $66 \mathrm{mgm}$. & $29.5 \%$ \\
\hline $\begin{array}{l}\text { VII. } \\
\text { WALKER. } \\
\text { Normal adult. }\end{array}$ & $\begin{array}{l}\text { One stool in } 24 \text { hours. } \\
\text { Fat: Some masses of cal- } \\
\text { cium and colorless soaps. No } \\
\text { splinters or needles. Rare } \\
\text { neutral fat drop. }\end{array}$ & $\begin{array}{c}280 \text { mgm. } \\
28 \%\end{array}$ & $71 \mathrm{mgm}$. & $25 \%$ & $109 \mathrm{mgm}$. & $39 \%$ & $100 \mathrm{mgm}$. & $36 \%$ \\
\hline $\begin{array}{l}\text { VIII. } \\
\text { W YETH. } \\
\text { Normal adult. }\end{array}$ & $\begin{array}{l}\text { One stool in } 24 \text { hours. } \\
\text { Fat: Masses of calcium and } \\
\text { colorless soap. No splinters } \\
\text { or needles. No neutral fat. }\end{array}$ & $\begin{array}{c}210 \mathrm{mgm} . \\
21 \%\end{array}$ & $61 \mathrm{mgm}$. & $29 \%$ & $75 \mathrm{mgm}$. & $35.7 \%$ & $74 \mathrm{mgm}$. & $35.2 \%$ \\
\hline $\begin{array}{l}\text { IX. } \\
\text { BEAN. } \\
\text { Normal adult. }\end{array}$ & $\begin{array}{l}\text { One stool in } 24 \text { hours. } \\
\text { Fat: Masses of calcium and } \\
\text { colorless soaps. Some splin- } \\
\text { ters and needles. Few neu- } \\
\text { tral fat drops }\end{array}$ & $\begin{array}{c}290 \mathrm{mgm} . \\
29 \%\end{array}$ & $100 \mathrm{mgm}$. & $34.4 \%$ & $110 \mathrm{mgm}$. & $37.9 \%$ & $80 \mathrm{mgm}$. & $28.5 \%$ \\
\hline $\begin{array}{l}\text { X. } \\
\text { SHEEHAN. } \\
\text { Normal adult. }\end{array}$ & $\begin{array}{l}\text { One stool in } 24 \text { hours. } \\
\text { Fat: Masses of calcium and } \\
\text { colorless soaps. No splinters } \\
\text { or needles. No neutral fat. }\end{array}$ & $\begin{array}{l}221 \text { mgm. } \\
22.1 \%\end{array}$ & $64 \mathrm{mgm}$. & $28.9 \%$ & $86 \mathrm{mgm}$. & $38.9 \%$ & $71 \mathrm{mgm}$. & $32.1 \%$ \\
\hline $\begin{array}{c}\text { XI. } \\
\text { BRODIE. } \\
\text { Normal adult. }\end{array}$ & $\begin{array}{l}\text { One stool in } 24 \text { hours. } \\
\text { Fat: Masses of calcium and } \\
\text { colorless soap. No splinters. } \\
\text { No neutral fat. }\end{array}$ & $\begin{array}{l}204 \text { mgm. } \\
20.4 \%\end{array}$ & $58 \mathrm{mgm}$. & $28.4 \%$ & $75 \mathrm{mgm}$. & $36.7 \%$ & $71 \mathrm{mgm}$. & $34.8 \%$ \\
\hline
\end{tabular}


TABLE 1.-Continued.

\begin{tabular}{|c|c|c|c|c|c|c|c|c|}
\hline \multirow{2}{*}{ CASE. } & \multirow{2}{*}{$\begin{array}{c}\text { Character of Feces } \\
\text { and Microscopic Finding } \\
\text { of Fat Content. }\end{array}$} & \multirow{2}{*}{ 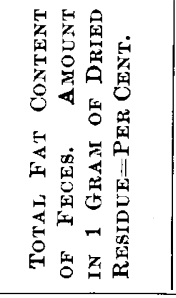 } & \multicolumn{2}{|c|}{ NEUTRAL FAT. } & \multicolumn{2}{|c|}{ FATTY ACID. } & \multicolumn{2}{|c|}{ SOAP. } \\
\hline & & & $\begin{array}{l}\text { Amount } \\
\text { in } \\
1 \text { Gram. }\end{array}$ & $\begin{array}{l}\text { Propor- } \\
\text { tion of } \\
\text { All Fat. }\end{array}$ & $\begin{array}{l}\text { Amount } \\
\text { in } \\
1 \text { Gram. }\end{array}$ & $\begin{array}{l}\text { Propor- } \\
\text { tion of } \\
\text { All Fat. }\end{array}$ & $\begin{array}{l}\text { Amount } \\
\text { in } \\
1 \text { Gram. }\end{array}$ & $\begin{array}{l}\text { Propor- } \\
\text { tion of } \\
\text { All Fat. }\end{array}$ \\
\hline $\begin{array}{l}\text { XII. } \\
\text { Adult. Diar- } \\
\text { rhea due to imper- } \\
\text { fect utilization of } \\
\text { fat. Cured by } \\
\text { cutting down fat } \\
\text { in diet. }\end{array}$ & $\begin{array}{l}\text { Very large stools; bulk in } \\
24 \text { hours four times the nor- } \\
\text { mal. Character, soft and un- } \\
\text { formed. Color, white and } \\
\text { glistening. } \\
\text { Fat: Excessive number of } \\
\text { splinters and needles. Many } \\
\text { neutral fat drops. }\end{array}$ & $\begin{array}{l}552 \text { mgm. } \\
55.2 \%\end{array}$ & 167 mgm. & $32 \%$ & $255 \mathrm{mgm}$. & $46 \%$ & $130 \mathrm{mgm}$. & $23 \%$ \\
\hline $\begin{array}{c}\text { XIII. } \\
\text { Adult. } \\
\text { Pernicious anemia. }\end{array}$ & $\begin{array}{l}\text { Stool large, partly formed. } \\
\text { Color, orange. } \\
\text { Fat: Some calcium and col- } \\
\text { orless soap masses (normal } \\
\text { amount). } \text { No splinters or } \\
\text { needles. No neutral fat.: }\end{array}$ & $\begin{array}{c}530 \mathrm{mgm} . \\
53 \%\end{array}$ & $160 \mathrm{mgm}$. & $30 \%$ & 170 mgm. & $31 \%$ & $200 \mathrm{mgm}$. & $37 \%$ \\
\hline $\begin{array}{l}\text { XIV. } \\
\text { Adult. } \\
\text { rhea with imper- } \\
\text { fect utilization of } \\
\text { fat. Cured by cut- } \\
\text { ting down fat in } \\
\text { diet. }\end{array}$ & $\begin{array}{l}\text { Stools, three in } 24 \text { hours. } \\
\text { Unformed, soft, of white, } \\
\text { glistening appearance. Ex- } \\
\text { cessive number of splinters } \\
\text { and needles. Rare neutral } \\
\text { fat drop. Some soap masses. }\end{array}$ & $\begin{array}{c}561 \underset{56.1 \%}{\mathrm{mgm}} . \\
.\end{array}$ & $155 \mathrm{mgm}$. & $27.7 \%$ & 327 mgm. & $58.3 \%$ & $78 \mathrm{mgm}$. & $14 \%$ \\
\hline $\begin{array}{l}\text { XV. } \\
\text { Adult. } \\
\text { Tubercular } \\
\text { peritonitis. }\end{array}$ & $\begin{array}{l}\text { Stools, three in } 24 \text { hours. } \\
\text { Unformed, soft, yellow-white. } \\
\text { Excessive number of splinters } \\
\text { and needles. Some neutral } \\
\text { fat drops. Some soap masses. }\end{array}$ & $\begin{array}{l}404 \mathrm{mgm} . \\
40.4 \%\end{array}$ & $145 \mathrm{mgm}$. & $35.9 \%$ & $201 \mathrm{mgm}$. & $49.8 \%$ & $57 \mathrm{mgm}$. & $14.1 \%$ \\
\hline \begin{tabular}{c|} 
XVI. \\
Adult. \\
Cancer of pancreas.
\end{tabular} & $\begin{array}{l}\text { Stools, four in } 24 \text { hours. } \\
\text { Large, soft, unformed. White } \\
\text { colored, glistening. } \\
\text { Fat: Much neutral fat in } \\
\text { drops. Numerous splinters } \\
\text { and needles. Calcium and } \\
\text { colorless soaps. }\end{array}$ & $\begin{array}{l}541 \text { mgm. } \\
54.1 \%\end{array}$ & $263 \mathrm{mgm}$. & $48.6 \%$ & $226 \mathrm{mgm}$ & $41.8 \%$ & $51 \mathrm{mgm}$. & $9.4 \%$ \\
\hline $\begin{array}{l}\text { XVII. } \\
\text { Adult. } \\
\text { Tubercular } \\
\text { peritonitis. }\end{array}$ & $\begin{array}{l}\text { Stools, two in } 24 \text { hours. } \\
\text { Partly formed, light color. } \\
\text { Fat: Numerous splinters } \\
\text { and needles. Some masses of } \\
\text { soap. No neutral fai. }\end{array}$ & $\begin{array}{l}321 \mathrm{mgm} . \\
32.1 \%\end{array}$ & $100 \mathrm{mgm}$. & $31.2 \%$ & $150 \mathrm{mgm}$. & $46.8 \%$ & $70 \mathrm{mgm}$. & $21.9 \%$ \\
\hline $\begin{array}{l}\text { XVIII. } \\
\text { Adult. Diar- } \\
\text { rhea due to faulty } \\
\text { utilization of fat. } \\
\text { Cured by diet. }\end{array}$ & $\begin{array}{l}\text { Stools, five in } 24 \text { hours. } \\
\text { Loose, glistening white. } \\
\text { Fat: Numerous splinters } \\
\text { and needles. Considerable } \\
\text { number of neutral fat drops. }\end{array}$ & $\begin{array}{l}466 \mathrm{mgm} . \\
46.6 \%\end{array}$ & $119 \mathrm{mgm}$. & $25 \%$ & $312 \mathrm{mgm}$. & $66 \%$ & $45 \mathrm{mgm}$. & $9.9 \%$ \\
\hline $\begin{array}{c}\text { XIX. } \\
\text { Cancer of pancreas }\end{array}$ & $\begin{array}{l}\text { Stools, four in } 24 \text { hours. } \\
\text { Loose, glistening white. } \\
\text { Fat: Numerous splinters } \\
\text { and needles. Large amount of } \\
\text { neutral fat. Calcium and col- } \\
\text { orless soap masses. }\end{array}$ & $\begin{array}{c}590 \mathrm{mgm} \\
59 \%\end{array}$ & $280 \mathrm{mgm}$. & $47 \%$ & 234. mgm. & $37 \%$ & $76 \mathrm{mgm}$. & $12 \%$ \\
\hline $\begin{array}{c}\text { XX. } \\
\text { Cancer of liver. } \\
\text { Jaundice. }\end{array}$ & $\begin{array}{l}\text { Stools, two in } 24 \text { hours. } \\
\text { Clay colored. } \\
\text { Fat: Many splinters and } \\
\text { and needles. Calcium and } \\
\text { colorless soaps. Rare neutral } \\
\text { fat drop. }\end{array}$ & $\begin{array}{c}660 \mathrm{mgm} . \\
66 \%\end{array}$ & $132 \mathrm{mgm}$. & $20 \%$ & $297 \mathrm{mgm}$. & $45 \%$ & $231 \mathrm{mgm}$. & $35 \%$ \\
\hline $\begin{array}{l}\text { XXI. } \\
\text { Pernicious } \\
\text { anemia. }\end{array}$ & $\begin{array}{l}\text { Stools, two in } 24 \text { hours. } \\
\text { Soft, partly formed, light } \\
\text { color. } \\
\text { Fat: Some calcium and } \\
\text { colorless soaps. Few splinters } \\
\text { and needles. No neutral fat. }\end{array}$ & $\begin{array}{c}460 \text { mgm. } \\
46 \%\end{array}$ & $135 \mathrm{mgm}$. & $29.4 \%$ & $170 \mathrm{mgm}$. & $34.9 \%$ & $145 \mathrm{mgm}$. & $33.4 \%$ \\
\hline
\end{tabular}


or soap masses. (Cases XIV, XV and XVII.) In some cases, for example, the cases of pancreatic disease, the neutral fat drops are present in great numbers with some increase in the splinters and needles. (Cases XVI and XIX.)

The full record of the experiment, however, shows that though a variation from the normal in the microscopic finding of the fat elements in the cases with abnormal quantities of fat as determined by chemical analysis is the rule, it is not a constant condition in all cases. Cases XIII and XXI, for example, with total fat contents of $53 \%$ and $46 \%$ respectively, or in both instances twice the normal quantity of fat, showed a microscopic finding similar to that found in the normal cases with low fat content, cases in which the amount of fat was but one third of that present in the two pathological cases. The analysis of the feces of these two cases showing a high fat content associated with a normal microscopic fat picture shows that all three forms of fat substance were increased, the amount of neutral fat, fatty acid and soap in one gram of dried residue being abnormal for all three. The proportions of the various forms of fat were practically normal, the soap averaging a little above the normal.

It follows, then, on the evidence of this research, that this method of determining the extent of the utilization of fat in the alimentary tract by the character of the microscopic fat finding is a reliable and useful method to this extent, that wherever the microscopic fat finding is marked, the character of this finding is a reliable index of the extent of fat utilization, the quantity and quality of the fat remains varying in accordance with the total quantity of fat present. The student is, therefore, justified in concluding wherever by this method of observation the microscopic fat finding shows a definite variation from the normal finding that an abnormal condition of fat utilization is present. The presence of a normal microscopic fat finding does not, however, necessarily indicate the existence of a normal utilization of fat. This method does not, therefore, serve as a reliable means of determining the normality or abnormality of the function of fat utilization for all cases. It does serve, however, for the determination of the existence of an abnormal condition of function in many cases. And as according to the experience of the author an abnormal microscopic fat finding is present in a majority of the cases where the total quantity of fat exceeds the normal, the method is of much service in the study of the condition of fat utilization in practical work.

In addition to the knowledge of the total quantity of fat in the test diet feces, whether or not this quantity is normal or increased, a knowledge of the proportions of the various fat substances which make up this total fat content, neutral fat, fatty acids and soaps, may be of value in connection with the study of any case with disturbance of function for fat utilization.

Of chief importance from this point of view is the estimation of the amount or proportion to the total fat content of the neutral fat quota. For while the estimation of the total fat tells us simply the extent of the utilization of fat in the alimentary tract, whether or not any disturbance of the general function of fat utilization, either digestion or absorption, one or both, exists, the estimation of the amount or proportion of neutral fat present is said to be an index of the condition of the special function of digestion of fat. The investigation of this point is said to be of much value in connection with the diagnosis of disease or disturbance of function of the pancreas. ${ }^{5}$

To determine whether or not our method of microscopic study of the feces gives us in addition to its indications in respect to the normality or abnormality of the total fat content any information in regard to this question of the normality or abnormality of the quantity or proportion to the total fat content of the neutral fat, that is, whether the method is of service for the determination of the condition of the special function of the digestion of fat, I have made a comparison of the microscopic findings of neutral fat and the actual amounts and proportion of neutral fat as established by chemical analysis in the cases included in my research.

The verdict of this experimental study upon this point is as follows: Neutral fat is not present in recognizable form under microscopic examination in the majority of normal cases under the Schmidt test diet, though, as already mentioned, considerable quantities of this form of fat, amounting on the average to $28 \%$ of the total fat as established by chemical analysis, are present in these cases. A few isolated neutral fat drops were, however, found in four of the normal cases examined. These 4 cases, 2 of them being children and 2 adults, all showed a total fat content above the average for all the normal cases, that is, they were cases of normal individuals with somewhat less than the usual capacity for utilizing fat. (Cases III, IV, VII and IX.) All of these normal cases showing neutral fat drops showed by chemical analysis quantities of neutral fat per gram of dried residue and proportions of neutral fat to the total fat content above the average in these respects for those normal cases which showed no neutral fat by microscopic examination.

The findings of the pathological cases, cases showing evidence of faulty utilization of fat by the presence of an abnormally large total fat content in the feces, were as follows: Seven cases showed neutral fat drops in greater or less number under microscopic examination. All of these cases showed by chemical analysis quantities of neutral fat per gram of dried residue above the maximum finding in this respect of the normal cases with no neutral fat in the microscopic finding. (Cases XIII, XIV, XV, XVI, XVIII, XIX and XX.) Four of these seven cases showed a percentage of neutral fat to the total fat content above the maximum finding in this respect of the s Müller: Zeitschr. für Klin. Med., xii, 1889, S. 101. Brugsch: Ibid., Iviii, 1906, Heft. 506. Deuscher: Corresponden ybl für Schiv. 
normal cases with no neutral fat in the microscopic finding. (Cases XII, XV, XVI and XIX.) The three remaining cases, although they showed an to actual increase in the quantity of neutral fat, gave percentages of this fat to the total fat content within the normal figures. (Cases XIV, XVIII and XIX.) Four cases showed large amounts of neutral fat by microscopic finding. Two of these, both cases with a very large finding of neutral fat by microseopic examination, showed proportions of neutral fat to the total fat content much higher than the maximum normal figure. (Cases XVI and XIX.) These were both cases of disease of the pancreas. Of the other two, showing moderately large findings of neutral fat by microscopic examination, one showed a normal proportion of neutral fat to the total fat content, the other a percentage slightly above normal. (Cases XII and XVII.) The actual quantity of neutral fat per gram of dried residue was much increased in all four cases. Two cases showed greatly increased quantities of neutral fat per gram of dried residue, with no recognizable neutral fat elements in the microscopic finding. (Cases XIII and XXI.) The percentages of neutral fat to total fat content in these two cases were normal. No case without a finding of neutral fat by microscopic examination increased over normal showed an increased percentage of neutral fat to the total fat present, though some such cases showed an actual increase over normal in the quantity of neutral fat present per gram of feces.

A summary of these results gives us the following verdict in regard to the question as to whether or not the character of the microscopic finding of the test diet feces gives us any definite indications as regards the actual neutral fat content, whether or not the proportion of this form of fat to the total fat is normal or increased. The presence of an abnormal finding of neutral fat by microscopic examination, even a large amount of neutral fat, does not necessarily indicate the existence of an abnormal proportion of neutral fat to the total fat content. On the other hand, wherever an abnormal proportion of neutral fat to the total fat content is present, as proved by chemical analysis, it has associated with it an abnormal finding of neutral fat by microscopic examination. We can, therefore, as the result of microscopic examination, rule out the existence of an abnormal percentage of neutral fat to the total fat content in all cases showing no neutral fat or very slight amounts by microscopic examination. In the cases with an abnormal finding by microscopic examination, we can say that there is a suggestion of an abnormality in the neutral fat content, particularly if this finding of neutral fat is of great extent, but we cannot, save possibly in extreme cases, come to a definite conclusion upon this point, except as the result of chemical analysis. When neutral fat drops are present, however, we can say, if disease of the colon is excluded, that the utilization of fat is less perfect than is the rule in normal cases, since all cases show- ing neutral fat drops in the microscopic finding had an actual quantity of neutral fat and a total fat content above the average normal amount.

As regards the question of the existence of any relationship between the character of the microscopic finding in fat elements and the presence of normal or abnormal proportions of the other two fat elements entering into the total fat content of the feces, the fatty acids and soaps, the findings of the experimental study are as follows:

Cases in which the microscopic finding shows a great excess of splinters and needles of fat substance, and in which these splinters and needles are the predominant fat finding, the other recognizable forms of fat, as neutral fat or soaps being present in the normal quantity or but slightly increased over normal, invariably showed a considerable increase over normal in the actual quantity per gram of dried residue, and in the percentage to the total fat present, of fatty acid. (Cases XII, XIV, XV and XVII.) ${ }^{6}$

No relation between the microscopic finding and the proportion of soap present could be established. As a rule, wherever an abnormal proportion of either neutral fat or of fatty acid was present, this increase appeared to be at the expense of the soap content of the total fat mixture, the actual quantity of soap per gram of dried residue often being below the normal average in these cases and the proportion of soap to the total fat content being much below normal. ${ }^{7}$ It seems clear, then, from the general considerations and the results of experimental research cited, that the method of study of the feces by macroscopic and microscopic examination as outlined by Schmidt and Strasburger serves in the hands of a trained observer as a reliable means of determining in many cases the condition of the functions for the general utilization of fat, whether these functions are normal or disturbed. The method is not absolutely accurate for all cases, since, as the experimental evidence shows, an increase over normal in the total fat content of the feces may be present without the occurrence of definite evidence of this fact in the microscopic finding. The experimental research, however, indicates conclusively that the method is reliable in respect to the condition of fat utilization to this extent, that wherever an abnormal fat finding by microscopic examination is present, an abnormal condition of utilization of fat can be assumed. As regards the question of the usefulness of the method for obtaining indications in regard to the condition of the function of digestion of fat as distinct from that of the general utilization of this substance, the evidences of the experimental study are as follows: The microscopic examination frequently reveals the

6 Deuscher, loc. cit., claims that an increased proportion of fatty acid is found in pancreatic disease. As, however, increased percentages of this form of fat are found in other conditions (see
Cases XII and XV), the significance of this finding is simply that of an increased fat content of the feces.

7 In regard to this finding of a low soap formation in the intestinal contents, see Deuscher, loc. cit. 
presence of an increased quantity over normal of neutral fat in the feces in the finding of an abnormal number of neutral fat drops, the results of experiment proving that such an abnormal microscopic finding of neutral fat has always associated with it an actual increase over the average normal finding in the total quantity of neutral fat in the feces. If the presence of an increased quantity of neutral fat per gram of dried residue or in the twenty-fourhour excretion is evidence of a disturbance of the function of digestion of fat, then the method does in many cases give us some indication of the existence of abnormal function in this respect. If, however, the criterion of the existence of a disturbance in the digestion of fat is the presence of an increased proportion of neutral fat to the total fat content over the normal finding, that is, the finding of $30 \%$ or more of the total fat in the form of neutral fat, then the method of microscopic examination is not a reliable index of the condition of digestion of fat, since an increased percentage of neutral fat to the total fat is not always found associated with an abnormal microscopic finding of neutral fat. To definitely determine this point for all cases we must have recourse to the chemical analysis. We can, however, from the indications of our experimental work, rule out the existence of such an increased proportion by our microscopic study in any case showing a normal microscopic finding as to neutral fat, since all cases with increased proportion of neutral fat to the total fat show an abnormal microscopic finding in this respect. This concludes the considerations of the experimental evidence obtained in regard to the accuracy of our method for the study of the functions of fat utilization.

As regards the subject of the general usefulness of this method of the macroscopic and microscopic study of the food contents of the test diet feces in clinical work, we can say definitely that this uscfulness is very great. The method does not, of course, provide us with a complete knowledge of the condition of function for the digestion and absorption of the various forms of food included in our dict. It tells us nothing, for example, in regard to the state of proteid or carbohydrate absorption, its indications in regard to the utilization of these two forms of food substance, consisting only of evidences of the condition of the function of digestion of one special form of proteid substance, meat fiber, and one form of carbohydrate substance, starch. For indications in regard to these functions, the absorption of proteid and carbohydrate, as also for exact indications of the extent of disturbance of function of fat utilization, or the proportionate quantities of the various forms of fat substance present, we are dependent upon chemical analysis. $^{8}$ For such information as it does provide, however, the method is of distinct use in general clinical work.

8 A simple means of determining the extent of utilization of carbohydrates, known as the fermentation test, has been developed by Schmidt and Strasburger. Die Faeces des Menschen. Schmidt und
Strasburger.
THE MUNICIPAL HOSPITAL FOR ADVANCED CONSUMPTIVES IN BOSTON.*

BY EDWIN A. LOCKE, A.M., M.D., Chief of Staff Boston Consumptives' Hospital; Second Assistant Visiting Physician, Boston City Hospital; Assistant in Clinical Medicine, Harvard Medical School; AND

SIMON F. COX, M.D. Superintendent, Boston Consumptives' Hospital.

Through a comprehensive organization under municipal control, the city of Boston is attempting to solve the local problem of controlling tuberculosis. This campaign has been organized along the broadest and most comprehensive lines, and brings into co-operation all the public and private agencies which are directly or indirectly concerned in this special work. Since the state provides ample sanatorium accommodations in the State Sanatorium at Rutland for all consumptives in the incipient stage, our plan has naturally been made to include the care of all other cases. It is the purpose of the organization to have examined and permanently recorded at the Out-Patient Department (Dispensary) of the Boston Consumptives' Hospital, as a central bureau, all cases of tuberculosis in the city, except those who may have a private physician. So far as possible the incipient cases are sent to the State Sanatorium, in some instances the board of the patient while there being paid by the Consumptives' Hospital, and in all cases the family kept under supervision. All other cases remain under the control of the Consumptives' Hospital, the particular disposition being in accordance with the scheme described below.

While admitting that the great mass of the consumptive poor must of necessity be treated and supervised in their homes, we believe that hospital care should be provided for certain classes; i. e., first, all destitute cases; second, all those who, because of ignorance, carelessness or indifference, are a menace to the community; and third, the majority of all dying cases. The strict isolation of all these classes we believe to be absolutely essential to the control of the spread of the disease, and we are, therefore, attempting to furnish institutional treatment for a very large group of the advanced consumptives. For these various classes, our plan makes certain provisions which are, perhaps, somewhat unique, and in part, at least, overcome the various serious difficulties attending such work. We are at present carrying out plans for the erection of a series of institutions adapted to this purpose. Some of these are already finished; others are now being built.

With reference to the hospital facilities needed, we have roughly divided all advanced cases into four general groups:

1. Those in the last stages, or the hopeless, and, in many instances, dying, cases. These, in consequence of the late stage of the disease, in which the sputum is, as a rule, more abundant, are clearly the greatest danger to others. As a

* Prepared for the International Congress on Tuberculosis, held 